\title{
O cinema de guerra da Ceilândia:
}

\section{As máquinas de Adirley Queirós contra a utopia de Brasília}

\section{The war cinema from Ceilândia:}

\section{Adirley Queirós' machines against Brasília's utopia}

\section{Cezar Migliorin}

Psicoterapeuta e Professor do Departamento de Cinema e Vídeo e do PPGCine/UFF. Doutor em Comunicação e Cultura pela UFRJ e pela Soubonne Nouvelle (França). Universidade Federal Fluminense, Programa de Pós-Graduação em Cinema e Audiovisual, Niterói (RJ), Brasil.

\section{Felippe Schultz Mussel}

Professor do Departamento de Comunicação Social da PUC-Rio e Mestre em Comunicação Social pela UFF. Pontifícia Universidade Católica do Rio de Janeiro, Departamento de Comunicação, Rio de Janeiro (RJ), Brasil.

\section{Apresentação}

Na cena final de Branco sai, preto fica (2015), uma série de desenhos retrata o bombardeio de Brasília e a destruição de seus principais edifícios modernistas. O longa-metragem, misto de documentário e ficção científica dirigido por Adirley Queirós, se encerra ao som do funk de MC Dodô enquanto assistimos ao ataque terrorista: Bomba explode na cabeça estraçalha ladrão / Fritou logo o neurônio que apazigua a razão / Eu vou cobrar e com certeza a guerra eu vou ganhar / Os trutas e as correrias vão me ajudar. 
Ao lançar mão da violência explícita, o cinema realizado por Adirley se distingue em meio à produção brasileira contemporânea. De certo que podemos incluir seus filmes como exemplos de uma ampla filmografia recente "que toma as metrópoles brasileiras como espaços privilegiados de suas inquietações" (PORTUGAL, 2016, p. 10). Trata-se de filmes que absorvem as cidades não apenas como cenários ou temas de seus roteiros, mas o fazem ocupando e inventando outras cidades, sobrepondo à cena urbana uma cena cinematográfica, forjando outros recortes dos espaços e dos tempos, outros rearranjos materiais e subjetivos do real. Filmes que estabelecem com os sujeitos e com os elementos urbanos "um conjunto de relações que longe de constituir uma informação sobre a cidade, acabam por estabelecer com ela um papel fundante" (MIGLIORIN, 2011, p. 163). Diante das transformações impostas às cidades brasileiras na entrada do século XXI, o cinema nacional constrói uma linguagem imbricada aos espaços urbanos, se contrapondo de forma mais ou menos declarada aos projetos desenvolvimentistas que se impõem.

Nesse contexto, os filmes dirigidos por Adirley - em especial Branco sai, preto fica (2015) e A cidade é uma só? (2011), duas obras que analisaremos de forma mais detida - propõem um tipo de resistência singular, em que as suas imagens e sons assumem formas bélicas, a tela se revela um campo de batalha contra uma cidade: Brasília. Uma batalha não apenas contra a cidade de concreto construída no início dos anos 1960; mas contra a segregação social, o racismo, a violência policial, a especulação imobiliária; contra essas e outras formas de espoliação derivadas daquele projeto utópico de cidade. A capital é o alvo, porém não é de Brasília que esse cinema se insurge, mas de outro lugar: Ceilândia, maior cidade-satélite da periferia do Distrito Federal, erguida dos escombros das remoções que, no final dos anos 1960, abandonaram milhares de famílias à própria sorte em uma região inóspita bem longe do Plano Piloto, tragédia que o cineasta remonta em A cidade é uma só?.

Se Brasília é constantemente apresentada como uma cidade neutra, lugar que abrigaria as disputas políticas dentro dos seus prédios, palácios e gabinetes, o cinema de Adirley desloca as batalhas para a cidade, para o seu espaço urbano. Há nessa batalha um esvaziamento de qualquer pretensa neutralidade do projeto de Brasília, explicitando nos filmes as marcas históricas e as fissuras do presente que atestam como aquela cidade foi, e é ainda, forjada na exclusão, no afastamento e no silenciamento do povo.

Pois tanto quanto marcar sua exterioridade em relação a Brasília, seus filmes investem de forma vigorosa na construção de narrativas próprias da Ceilândia, em histórias que invariavelmente fabulam a 
revanche da periferia contra a capital. Uma insurgência alavancada não apenas pelos personagens, mas por diferentes tipos de máquinas convocadas para o embate: carros, cadeiras de rodas, pernas mecânicas, aparelhos de som, antenas de rádio, computadores, scanners, elevadores, containers, bombas e outros aparatos de naturezas diversas. Enquanto objetos cenográficos, as máquinas assumem um papel determinante na medição, no agenciamento entre os personagens e as cidades, se revelando elementos essenciais para as estratégias de ataque à Brasília.

Para além do seu papel narrativo e dramático, estamos interessados em um certo funcionamento das máquinas da Ceilândia, um modo de operar que reorganiza a relação entre os corpos e os espaços idealizados pelo urbanismo e pela arquitetura modernista. Mais do que simplesmente explodir a capital, o cinema de Adirley questiona o projeto de Brasília em suas bases utópicas, desregulando as suas estruturas disciplinares.

\section{Desorganizando a grande máquina}

São conhecidos os arranjos da sociedade disciplinar, aqueles que atuam na distribuição dos indivíduos em espaços classificatórios, hierarquizados e sob variadas formas de vigilância e confinamento. Michel Foucault (2002, p. 119) nos ensina como essa tecnologia se manifesta, em última instância, nos domínios do corpo, nos seus membros, gestos, comportamentos e funcionalidades, concentrando e compondo os corpos no tempo e no espaço de modo a multiplicar um sistema de diretrizes. A disciplina atua no corpo como uma "maquinaria de poder que o esquadrinha, o desarticula e o recompõe. A disciplina fabrica assim corpos submissos e exercitados, os chamados 'corpos dóceis'".

Tal maquinaria, profundamente estudada no âmbito das instituições (a família, a escola, o exército, a fábrica, a prisão, o hospital), encontra paralelo no ideário da arquitetura modernista que inspirou Brasília, "uma cidade planejada para o trabalho eficiente e ordenado" (BRAGA, 2010, p. 162), como justificou Lúcio Costa no relatório anexado ao seu projeto para a nova capital. Le Corbusier, grande influenciador dos modernistas brasileiros, justificava que os problemas enfrentados pelas metrópoles em meados do século XX eram "o fruto amargo de cem anos de maquinismo sem direção", para os quais apenas os arquitetos poderiam "receitar o remédio exato", os únicos capazes de "pôr a grande máquina em funcionamento" (HOLSTON, 1993, p. 63, 57 e 67, respectivamente). A máquina, cuja potência de 
associação com os corpos e com os elementos urbanos foi tão exaltada por cineastas como Dziga Vertov, adquire na perspectiva dos arquitetos modernistas uma dimensão essencialmente teleológica, em que a cidade funcionaria tal qual uma linha de montagem fordista.

Desenhado sobre um plano cartesiano, o Plano Piloto de Brasília é a base do seu esquema disciplinar, em que dois eixos perpendiculares (Norte e Sul) determinam a localização espacial na cidade, definindo os endereços pela combinação de números e siglas correspondentes às suas "funções urbanas", como moradia, escola, igreja, parque, polícia, comércio, administração pública: SQN 403, SGAS 602, CLS 204, EQS 114. A disciplina, essa "arte de dispor em fila", como define Foucault, funciona por um sistema de elementos intercambiáveis, como são as quadras residenciais e comerciais da capital, todas idênticas, tendo como diferença apenas o lugar que ocupam na escala da cidade, o ponto em que cruzam uma linha e uma coluna. As ruas e esquinas foram substituídas por um sistema de avenidas e rotatórias desimpedidas, em que tanto motoristas como os raros pedestres estão invariavelmente cercados por grandes áreas verdes e descampadas. Essa monotonia do desenho urbano, tendo o automóvel como símbolo de mobilidade, além de apontar para uma domesticação dos corpos, propõe uma experiência urbana marcada pelo privado: privar-se do outro, do risco da alteridade e da efervescência política das ruas. Em Brasília, a disciplina se quer "limpa” e racional. Os corpos não precisam ser aprisionados, basta que sejam tabulados no espaço (FOUCAULT, 2002, p. 125).

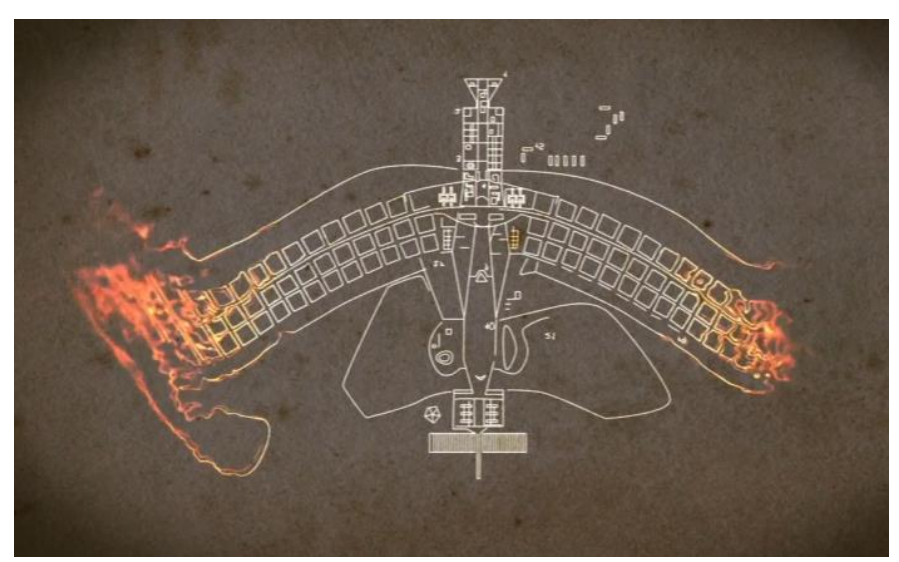

Cena de abertura de $A$ cidade é uma só? Crédito: frame do filme.

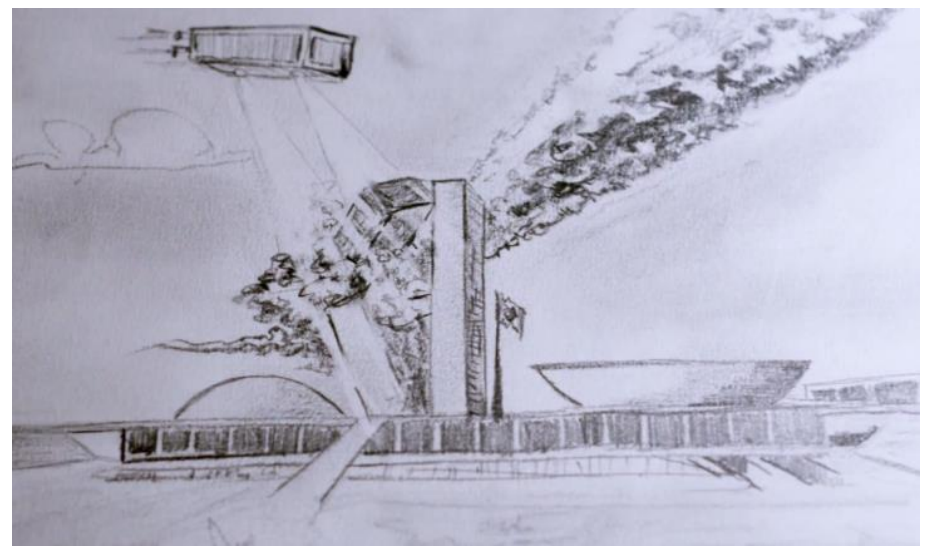

Cena final de Branco sai, preto fica. Crédito: frame do filme.

Logo na abertura de A cidade é uma só?, o desenho do Plano Piloto surge em animação na tela enquanto ouvimos o motor de um carro. Quando o motor desliga, o mapa da cidade começa a queimar e 
desaparece em chamas. O carro, um combalido Santana, passará boa parte do filme vagando pelas vias expressas do Plano, conduzido pelos personagens Zé Bigode e Dildu. Desorientados pela arquitetura repetitiva e pela sinalização alfanumérica, eles embaralham a combinação de letras e números que nomeiam os endereços: "saída Sul, Eixo W, Zona Central", "olha, a saída é 215, agora é 400, passou pra 216, lá vem o $120 . .$. o que é isso!?", "se você achar uma alma viva por aí a gente pergunta". Andando em círculos, a fluidez do tráfego imaginada pelo urbanista se converte em uma cena caótica que inclui tentativas arriscadas de cruzar as autopistas na contramão: “Como é que sai daquil?", grita desesperado Dildu. O automóvel, muitas vezes associado a um tipo de urbanidade narcótica, se converte em uma máquina insubmissa aos traçados modernistas.

Onipresente nos filmes de Adirley, o Santana não é apenas o meio de transporte dos personagens. Além de ferramenta de trabalho do especulador imobiliário Zé Bigode em sua busca por terrenos baratos, o veículo será adaptado para a campanha eleitoral quixotesca de Dildu, recebendo uma aparelhagem de som com a qual o candidato anuncia com um jingle as suas propostas de reparação histórica para os moradores da Ceilândia removidos de Brasília. A revanche aqui não se faz apenas pelas palavras gritadas por Dildu no microfone enquanto o carro circula pela cidade-satélite, mas sobretudo por atacar Brasília tomando posse dos mesmos instrumentos com os quais fora atacado no passado: foi por meio de uma outra campanha, a Campanha de Erradicação das Invasões (CEI, nome que batizou a Ceilândia), também com jingles e carros de som, que nos anos 1960 o governo de Brasília tentou manipular os "invasores" para abandonarem Brasília e irem morar longe dali.

Em outro filme dirigido por Adirley, o curta-metragem Dias de greve (2009), o mesmo Santana conduz os operários grevistas em passeios sem rumo pela Ceilândia, bebendo vinho em um garrafão e ouvindo música alta, transformando os trajetos em momentos de ócio e alegria para além das responsabilidades com o sindicato. $O$ automóvel se converte em uma extensão da corporeidade pujante daqueles indivíduos. Em vez de tomar o carro como máquina de erosão da vida pública, os filmes investem vigorosamente em seus imbricamentos: a máquina exige dos corpos (exausto, Zé Bigode quase dorme ao volante no retorno para a Ceilândia) tanto quanto os corpos exigem das máquinas (em outra cena, é o motor do Santana que "morre", obrigando Dildu a empurrá-lo para pegar no tranco). Trata-se, em verdade, de intensificar o caráter dessas trocas, recodificando-o no mesmo gesto, fazendo da própria necessidade e funcionalidade do automóvel no Distrito Federal uma cena subversiva. 
Sobre a potência do automóvel no cinema, vale fazer aqui um breve desvio com Abbas Kiarostami. Elemento recorrente nos seus filmes, os carros assumem papel semelhante ao que percebemos em Adirley, em que o enclausuramento da vida privada se conjuga com uma transparência em relação ao espaço público externo. É circulando de carro pelas cidades que os personagens do cineasta iraniano desfrutam de uma relação de intimidade em um país cujos regimes políticos e tradições religiosas condicionam os indivíduos a um comportamento social bastante regulado, com normas distintas daquelas que conhecemos nas cidades ocidentais. O automóvel é um espaço de resistência, lugar onde emergem desejos, segredos e tensões dos indivíduos - onde um homem planeja seu suicídio em Gosto de cereja (1997), onde a mãe e a prostituta conversam sobre a vida em Dez (2002).

Para Kiarostami, dirigir um carro tem algo de cinematográfico: "ao volante estamos como no cinema, com uma tela em cinemascope diante de nós, duas telas laterais e a possibilidade de realizar um travelling extraordinário no meio da cidade ou da natureza". O carro proporciona aos seus atores, sobretudo às mulheres, uma dramaticidade construída no limite tênue com a vida pública que se avizinha do outro lado do para-brisa: "Nos meus filmes, o carro é ao mesmo tempo uma liberdade e uma coerção, tanto para mim como para meus personagens" (BERNARDET, 2004, p. 39 e 43, respectivamente). De forma análoga, Adirley não se rende ao funcionamento do carro como máquina de passividade e individualidade, onde a cidade lá fora seria um mero "lugar de passagem", um não lugar, mas faz do carro um espaço dramático; e da janela, um ecrã cinematográfico, cujas imagens atravessam seus personagens e disparam suas performances, sem deixar de intimidá-los. Em seu confronto com Brasília, o cinema de Adirley se apropria de uma premissa-símbolo do urbanismo modernista, o seu "elogio à máquina", mas acaba por devolver à utopia de Brasília uma outra potência maquínica.

\section{Arquiteturas de gambiarras}

Ao tomar a cidade e os elementos urbanos como agenciadores de sua inscrição visual e sonora, estamos pensando no cinema como uma complexa máquina em que o corpo humano está destituído do ponto de vista privilegiado na elaboração material e subjetiva da cidade. Trata-se de considerar, sem hierarquias, a existência de uma heterogeneidade de focos de subjetivação - materiais e imateriais - que se encadeiam de forma instável e imprevisível no tecido urbano. 
Pensando com Gilles Deleuze e Felix Guattari, a noção de máquina se multiplica para além da materialidade dos aparatos, como um automóvel ou uma bomba. Não se trata, porém, de afirmar que um corpo absorve as capacidades mecânicas dos objetos técnicos, ou que estes adquirem uma dimensão orgânica. Um corpo não funciona como uma máquina, ou vice-versa. Uma máquina é feita de ligações, de um conjunto de vizinhanças entre humanos, objetos, monumentos, animais, etc. A máquina não é a coisa em si, mas uma espécie de linha que atravessa os atores e os faz funcionar juntos (DELEUZE; PARNET, 1998, p. 128). O corpo e o carro são "peças" ou "engrenagens" da máquina automotiva e, na mesma medida, são em si "pequenas máquinas" que traçam suas próprias conexões, fluxos, cortes. Os agenciamentos maquínicos são conexões que clamam por uma heterogeneidade de elementos com naturezas e dimensões múltiplas, feitos por ligações sempre provisórias, instáveis e imprevisíveis. Em uma palavra: gambiarras.

Assim, o candidato Dildu se liga ao microfone, às caixas de som e ao carro que projetam sua voz pela Ceilândia. Assim, as letras e números do Plano Piloto interceptam os personagens humanos, que por sua vez as desorganizam, desviam dos seus caminhos pré-estabelecidos, entram com o carro pela contramão. "Morreu foi muita gente aqui", diz Dildu enquanto observa os edifícios modernistas, evocando a história dos trabalhadores cujos corpos acabaram soterrados pelo concreto quando da construção de Brasília ${ }^{1}$. Os prédios monumentais da capital, as casas todas gradeadas da Ceilândia, a Esplanada dos Ministérios, os campos de futebol de terra batida da cidade-satélite, uma longa estrada em linha reta ou os trilhos suspensos do metrô: as formas da arquitetura e do urbanismo "nos interpelam de diferentes pontos de vista: estilístico, histórico, funcional, afetivo, ético, (...) podendo trabalhar tanto no sentido de um esmagamento uniformizador quanto no de uma ressingularização libertadora da subjetividade individual e coletiva" (GUATTARI, 1992, p. 140). As cidades são, na expressão que Guattari toma emprestada de Lewis Mumford, megamáquinas, cujo modo de funcionamento é resultado de uma variedade infinita de outras máquinas, cada qual com suas singularidades.

Nos filmes de Adirley, são evidentes os contrastes entre as arquiteturas da Ceilândia e o visual etéreo, o formalismo e a homogeneização dos prédios de Oscar Niemeyer. Em Branco sai, preto fica, a casa de Sartana é uma espécie de galpão feito de restos de peças metálicas, onde ele trabalha consertando

\footnotetext{
${ }^{1}$ Algumas das histórias trágicas da construção de Brasília, incluindo um massacre de trabalhadores nos anos 1970, são narradas no seminal Conterrâneos Velhos de Guerra (1991), documentário dirigido por Vladimir Carvalho.
} 
pernas mecânicas como a sua, marca que guarda da invasão truculenta da polícia em um baile na Ceilândia nos anos 1980. Também sobrevivente da violência do Estado, o cadeirante Marquim vive em um bunker subterrâneo que também abriga sua rádio pirata. Repletas de gambiarras, as casas funcionam como uma extensão daqueles corpos mutilados.

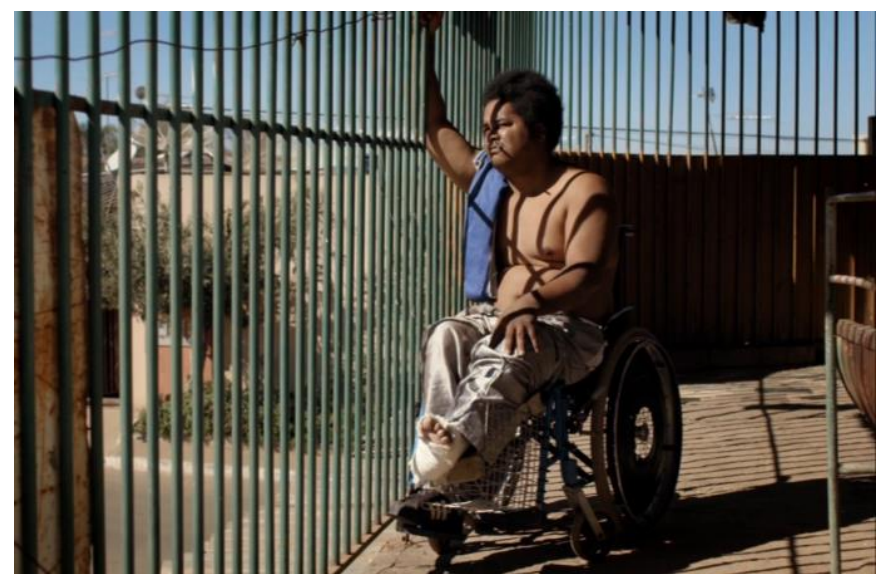

Marquim em cena de Branco sai, preto fica. Crédito: frame do filme.

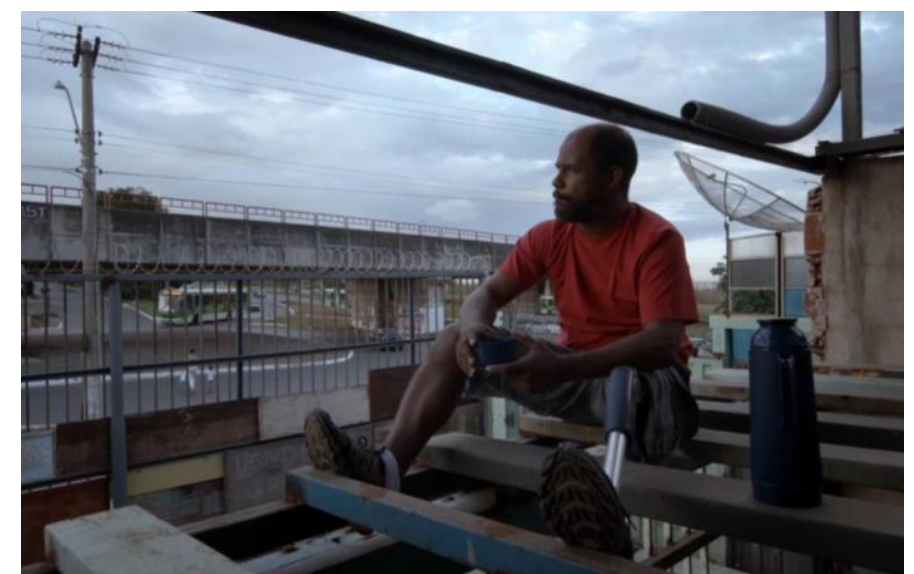

Sartana em cena de Branco sai, preto fica. Crédito: frame do filme.

Nas cenas de Sartana em casa, sua composição no quadro busca traçar uma relação de contiguidade entre membros do seu corpo e as vigas de aço aparentes que sustentam a construção, como se a perna mecânica e vigas de aço fossem "um corpo só". Os elevadores que conduzem Marquim, o sistema de roldanas em que ele guarda sua coleção de discos, e outros gatilhos do cenário, formam um mecanismo adaptado às suas necessidades físicas, o que não apenas amplia a sua mobilidade, mas faz do seu corpo o "molde" de sua casa. Aí se encontra o contraponto essencial com os paradigmas modernistas, em que tanto a serialidade e a grandiosidade das edificações como as imensas faixas de terra descampadas se revelam um projeto dissonante e opressivo em relação à escala do corpo humano.

Levando ao limite distópico a privatização da vida pública, na Ceilândia de Branco sai, preto fica, a vida dos personagens se vê restrita aos espaços fechados de suas casas, verdadeiras fortalezas protegidas por sistemas de segurança e por toques de recolher da "polícia do bem-estar social". Diante das ruas desertas, onde há apenas carros circulando, Sartana fala sobre o choque que sentiu quando saiu do hospital depois do atentado: “A gente ficava muito na esquina da escola sentado numa manilha, era ali que a gente conversava, bolava os nossos passinhos. (...) A cidade toda era parte da minha vida, parece que cortou aquilo tudo de mim". A amputação de sua perna coincide com a disjunção da cidade. A violência 
que dilacerou seu corpo faz parte do mesmo projeto que descorporificou as ruas, que arrancou os pobres de Brasília e os descartou para fora da capital.

\section{Cinema de guerra}

A revanche do cinema da Ceilândia não se resume aos edifícios modernistas sendo bombardeados ou à queima do mapa do Plano Piloto. Sua guerra contra o projeto de Brasília ultrapassa os simbolismos, e nada tem de "imaginária", como os corpos de Marquim e Sartana insistem em lembrar. Pensar o cinema como "máquina de guerra" também não tem a ver com a representação de qualquer ataque militar ou a expulsão de inimigos para conquista de territórios. Nos termos de Deleuze e Guattari, "é preciso conseguir pensar na máquina de guerra como sendo ela própria uma pura forma de exterioridade, enquanto que o aparelho de Estado constitui a forma de interioridade que tomamos habitualmente por modelo, ou pela qual temos o hábito de pensar" (DELEUZE; GUATTARI, 2012, p. 15). Uma máquina de guerra possui sempre uma posição de exterioridade em relação ao aparelho do Estado - este sim invariavelmente militarizado. Estado aqui percebido como qualquer tipo de poder central com aspirações hegemônicas e totalizantes como, por exemplo, operam os próprios Estados Nacionais por meio de seus governos. Sua guerra não se faz visando extinguir ou substituir o Estado, tomando para si o poder, mas produzindo fraturas, deslocamentos e perturbações nos pontos de vista centralizadores, no mesmo gesto escapando ao exercício do controle e se dissolvendo: entre as dunas do deserto, como os bandos de nômades; nas ruas e becos da cidade, como as gangues de arruaceiros.

A exterioridade guerreira do cinema de Adirley em relação ao Estado-Brasília também não se assenta na posição geográfica da Ceilândia. Não bastaria dizer que os filmes são máquinas que atacam o centro porque realizados por pessoas da periferia; ou que é um ataque vindo dos que não têm representatividade dentro do Estado. Sua guerra é empreendida contra as "puras" interioridades opressivas da própria Ceilândia, aquelas que são introjetadas enquanto representações estanques dos corpos periféricos, quase sempre marcados por algum tipo de carência, violência ou exotismo. Pois é a própria representação, como "a tendência a reproduzir-se idêntica a si através de suas variações, [mas] facilmente reconhecível nos limites de seus polos" (DELEUZE; GUATTARI, 2012, p. 25), uma forma de 
apropriação do real transformado em sua imagem positiva, que se revela uma operadora fundamental da forma-Estado. Ela opera assim estabelecendo o campo restrito do que é e do que não é representável.

Branco sai, preto fica produz um comentário mordaz às lógicas de representações interiorizadas. Viajando no tempo dentro de um contêiner, o agente terceirizado do Estado Dimas Cravalanças pousa na “antiga Ceilândia” vindo do ano 2073. Sua missão no território do passado é encontrar indícios dos crimes cometidos pelo próprio Estado brasileiro contra populações negras e marginalizadas. Seu caso de investigação é a violenta batida policial no baile do Quarentão, que vitimou Sartana e Marquim. "Produza provas, Cravalanças!", ordena a mensagem em vídeo projetada na lataria do contêiner. Após longa busca, apenas um material será capaz incriminar o Estado e "ressarcir as famílias": as próprias entrevistas dos personagens Sartana e Marquim gravadas para o "documentário" Branco sai, preto fica, as quais ouvimos em off desde o início do filme, depoimentos em que relatam em detalhes os fatos trágicos. Enviados para o futuro, os testemunhos em vídeo seriam então a representação incontestável das espoliações sociais e subjetivas sofridas pelos moradores das periferias de Brasília.

Avançando no tempo em relação à sua própria narrativa distópica, o filme projeta mais uma camada de futuro, quando enfim o Estado terá reparado seus danos às populações excluídas. Nesse processo de reparação social alavancado pelas "imagens do passado" enviadas para um futuro, são as próprias utopias do cinema que Adirley coloca em questão. Com engenhosidade, Branco sai, preto fica insinua uma autocrítica acerca do uso recorrente da "voz do oprimido" como imagem comprobatória das mazelas sociais, estratégia contumaz do cinema documental. Imagens-denúncia, as vozes e os corpos periféricos cumpririam a função de comprovar o racismo e a violência policial na Ceilândia. Vistas pelo tribunal do futuro, as imagens seriam capazes de, enfim, incluir os excluídos.

Pois é exatamente esse sistema de representações que o filme ironiza e de que busca esquivar-se ao propor a explosão de Brasília e, no mesmo gesto, a implosão do próprio grupo insurgente da Ceilândia. No roteiro do filme, a bomba se revela um evento eletromagnético que ameaça o futuro de toda humanidade, impedindo assim que os próprios rebeldes sejam "ressarcidos" ou que constituam um governo. Após acionar a bomba, Marquim queima todos os papéis com seus planos de guerra, assim como os discos que tocava em sua rádio. Uma máquina de guerra, em sua natureza distinta do aparelho do Estado, não é um projeto a ser concretizado. São acontecimentos, como a campanha eleitoral quixotesca de Dildu. Assim como os personagens de Branco sai, preto fica não tomam poder, tampouco esse é um 
objetivo plausível para o candidato Dildu em A cidade é uma só?. Interessa a ele, antes, apropriar-se do universo eleitoral para escrachá-lo, quando uma proposta de indenização para os moradores removidos se confunde com a promessa de exibir filmes de karatê. Sua campanha de guerra é, antes de tudo, um ataque às campanhas cínicas e manipuladoras da "grande máquina". A Campanha de Erradicação de Invasões e a campanha para presidente de Dilma Rousseff, que invade a Ceilândia na cena final do longa, são reconhecíveis enquanto formas análogas, uma variação da mesma forma-Estado, da forma-Brasília.

\section{Desvios pela ficção}

Como os rebeldes que implodem a sua própria rebelião, um aparente contrassenso marca outros personagens de Adirley. Politicamente incorreto, o jingle do candidato Dildu é ritmado por tiros de revólver, como nos raps gangsta que fazem apologia à criminalidade. Zé Bigode, por sua vez, é ao mesmo tempo agente da especulação imobiliária e cabo eleitoral de Dildu, ajudando a divulgar suas propostas em favor dos moradores removidos no passado. Em Branco sai, preto fica, Marquim vai tentar explorar o trabalho do seu comparsa Jamaika para construir a "bomba sonora" que vingaria o passado de opressão da Ceilândia. Por fim, a própria bomba será o evento que impede a realização de uma utopia social. Para Adirley, a contradição é um modo de funcionamento privilegiado dos seus filmes e dos seus personagens, uma estratégia contumaz para desestabilizar os modelos de representação da periferia.

Pois assim também procedem os operários em Dias de greve ao recusar as orientações do sindicato, enfraquecendo a greve na serralheria para trabalhar no barracão da escola de samba do patrão, priorizando o carnaval à luta de classes: "uma greve necessita de ordem!", diz um dos sindicalistas, enfurecido, encarnando a utopia trabalhista. Ao que um dos fura-greve responde: “ordem pra mim é a escola entrando bonitinha na avenida". Essa contradição no interior da representação revolucionária do proletariado - que nos lembra do dilema vivido por pai e filho em Eles não usam black tie (Leon Hirszman, 1981) - se reproduz também dentro do próprio sindicato, que faz um acordo com o patronato para pacificar a serralheria. Eis que, no fim do curta, o patrão e os grevistas desfilam juntos em êxtase no carnaval, para no dia seguinte retornarem ao trabalho na serralheria sem o requerido aumento de salários. Ainda assim, os trabalhadores mantêm uma postura impassível diante do patrão, um tipo de impavidez 
também vista em Dildu nas cenas finais de A cidade é uma só? cantarolando um rap, ou em Marquim logo após acionar a bomba que explode Brasília em Branco sai, preto fica.

As contradições e desvios de representação dos filmes de Adirley não apenas travam uma oposição ferrenha à utopia que idealizou e construiu Brasília, mas o fazem devolvendo a essa utopia seu caráter "de 'irrealidade', de montagem de palavras e imagens, próprio para reconfigurar o território do visível, do pensável e do possível" (RANCIÈRE, 2005, p. 62). Essa postura contrautópica dos personagens de Adirley nos remete aos arquivos dos personagens recuperados por Jaques Rancière no livro $A$ noite dos proletários: artesãos, sapateiros, alfaiates, tipógrafos que, em meados do século XIX, produziram textos em descompasso com o que os intelectuais socialistas da época neles projetavam. Seus devaneios noturnos, escritos em prosa e poesia, abririam um campo de possibilidades para além da representação do trabalho que marcaria historicamente aqueles operários. Da mesma forma, o cinema de Adirley se apropria da ficção que constitui toda forma de utopia para interrogar o próprio funcionamento do cinema enquanto máquina de representação.

Como apêndice, podemos ainda esboçar uma ideia de cinema político que se forja no cinema de guerra da Ceilândia; mais do que isso, pensar o gesto político que se apresenta como possibilidade no tensionamento bastante específico do binômio modernismo e exclusão. O caso singular brasileiro dos modos de exclusão inerentes ao ideal utópico modernista parece exigir um gesto político que não se configura nem por palavras de ordem, nem por exigências discursivas, mas por meios de fazer desabar os alicerces estéticos que sustentam aquele projeto de cidade. $O$ dano estético produzido com esse gesto não é, contudo, um pedido de correção do projeto ou de inclusão na cidade. Trata-se, simplesmente, de produzir fissuras, desvios nas ordens temporais e espaciais dos alicerces modernistas através do escracho, do humor, de um deslocamento das suas estruturas por algo improvável, externo.

Ao mesmo tempo, tais fissuras não se fazem sem alguma representação da pobreza, do racismo, da violência, em suma, das materialidades históricas já interiorizadas sobre a exclusão. Podemos então pensar na possibilidade de um gesto político que aponta em duas direções: para dentro das materialidades históricas e para fora, em ficções desviantes da própria materialidade. O projeto de Brasília passa assim a ser não apenas apontado como algo que violenta os corpos periféricos, mas como uma cidade impossível enquanto espaço de criação, por isso a necessidade de delirar no presente. 
Cezar Migliorin

ORCID: https://orcid.org/0000-0002-0212-0749 Universidade Federal Fluminense, Programa de Pós-Graduação em Cinema e Audiovisual, Niterói (RJ), Brasil Doutor em Comunicação e Cultura pela UFRJ e pela Soubonne Nouvelle (França) E-mail:migliorin@gmail.com

Felippe Schultz Mussel ORCID: https://orcid.org/0000-0002-0212-0749 Pontifícia Universidade Católica do Rio de Janeiro, Departamento de Comunicação, Rio de Janeiro (RJ), Brasil Mestre em Comunicação Social pela UFF E-mail:ppmussel@gmail.com

Recebido em: 29 de março de 2021.

Aprovado em: 11 de maio de 2021.

\section{Referências}

BRAGA, Milton. O concurso de Brasília: sete projetos para uma capital. São Paulo: Cosac Naif, 2011.

BERNARDET, Jean-Claude. Caminhos de Kiarostami. São Paulo: Companhia das Letras, 2004.

DELEUZE, Gilles e PARNET, Claire. Diálogos. São Paulo: Editora Escuta, 1998.

e GUATTARI, Félix. Mil Platôs: capitalismo e esquizofrenia 2. Vol. 4. Tradução Peter Pál Pelbart e Janice Caiafa. São Paulo: Editora 34, 2012.

FOUCAULT, Michel. Vigiar e punir: nascimento da prisão. Tradução Raquel Ramalhete. Petrópolis: Vozes, 2002.

GUATTARI, Félix. Caosmose: um novo paradigma estético. São Paulo: Editora 34, 2012.

HOLSTON, James. A cidade modernista: uma crítica de Brasília e sua utopia. São Paulo: Companhia das Letras, 1993. 
MIGLIORIN, Cezar. Escritas da cidade em Avenida Brasília Formosa e O céu sobre os ombros. Revista Ecopós, v. 14, p. 162-176, 2011.

PORTUGAL, Aline. Geografia de Espaços Outros: formas de ocupar e inventar as cidades no cinema brasileiro contemporâneo. Dissertação (Mestrado em Comunicação Social) - Universidade Federal Fluminense - Instituto de Arte e Comunicação Social. Niterói: IACS, 2016

RANCIÈRE, Jacques. A partilha do sensível: estética e politica. São Paulo: Ed. 34, 2005.

\section{Resumo}

O cinema de Adirley Queirós funciona a partir de uma lógica de confronto envolvendo duas cidades: Brasília, a capital brasileira erguida nos anos 1960; e Ceilândia, cidade-satélite do Distrito Federal para onde foram removidas milhares de famílias excluídas do projeto modernista de Brasília. Em suas tramas de insurreição da periferia contra a capital, os filmes de Adirley investem de forma recorrente na fricção entre os corpos dos personagens, as arquiteturas urbanas e diferentes tipos de máquinas. Atento a esses imbricamentos, o artigo recorre ao pensamento de Deleuze e Guattari para investigar como esse cinema de guerra forja seus ataques aquele projeto utópico de cidade.

Palavras-chave: Adirley Queirós; Brasília; cinema brasileiro contemporâneo; máquinas de guerra.

\section{Abstract}

Adirley Queirós' cinema works from a logic of confrontation involving two cities: Brasília, the brazilian capital built in the 1960s; and Ceilândia, a satellite city in the Federal District where to many of the families excluded from the modernist project of Brasília were removed. In its plots of insurrection of the outskirts against the capital, Adirley's films recurrently invest in the friction between characters's bodies, urban architectures and different types of machines. Aware of these imbrications, the article appeal to Deleuze and Guattari's thinking to investigate how this war cinema forges its attacks on that utopian city project.

Keywords: Adirley Queirós; Brasília; contemporary brazilian cinema; war machines. 


\section{Resumen}

El cine de Adirley Queirós trabaja desde una lógica de confrontación entre dos ciudades: Brasilia, la capital brasileña construida en los años sesenta; y Ceilândia, ciudad satélite del Distrito Federal donde fueron desalojadas miles de familias excluidas del proyecto modernista en Brasilia. En sus tramas de insurrección de la periferia contra la capital, las películas de Adirley invierten de forma recurrente en la fricción entre los cuerpos de los personajes, las arquitecturas urbanas y diferentes tipos de máquinas. Atento a estas imbricaciones, el artículo se basa en el pensamiento de Deleuze y Guattari para investigar cómo este cine de guerra fragua sus ataques a ese proyecto de ciudad utópica.

Palabras clave: Adirley Queirós; Brasília; cine brazileño contemporáneo; maquinas de guerra.

Este artigo é publicado em acesso aberto (Open Access) sob a licença Creative Commons Attribution Non-Commercial (CC-BY-NC 4.0), que permite que outros remixem, adaptem e criem a partir do seu trabalho para fins não comerciais, e embora os novos trabalhos tenham de lhe atribuir o devido crédito e não possam ser usados para fins comerciais, os usuários não têm de licenciar esses trabalhos derivados sob os mesmos termos. 